\title{
A CONTABILIDADE GERENCIAL EM MICRO E PEQUENAS EMPRESAS NO BRASIL: UMA ANÁLISE SOB A PERSPECTIVA DO CENÁRIO SOCIAL, ECONÔMICO E POLÍTICO
}

\section{ARTIGO ORIGINAL}

SANTOS, Nayara Nadja Rodrigues dos ${ }^{1}$

SANTOS, Nayara Nadja Rodrigues dos. A contabilidade gerencial em Micro e Pequenas Empresas no Brasil: Uma Análise sob a perspectiva do cenário social, econômico e político. Revista Científica Multidisciplinar Núcleo do Conhecimento. Ano 05, Ed. 07, Vol. 02, pp. 57-90. Julho de 2020. ISSN: 2448-0959, Link de acesso: https://www.nucleodoconhecimento.com.br/contabilidade/cenario-social

\section{RESUMO}

Entende-se por contabilidade gerencial a produção útil de informação para a administração com base em informações estratégicas que auxiliem no planejamento, na medição, avaliação e tomada de decisões na organização com base nessas análises. $O$ estudo foi pautado em uma revisão bibliográfica com base nas produções técnico-acadêmicas da área da Contabilidade com enfoque na Contabilidade Gerencial. O objeto desse livro serão as micro e pequenas empresas no Brasil sob a análise das práticas da contabilidade gerencial desenvolvidas por elas como ferramenta de apoio para a tomada de decisões. $O$ estudo foi realizado a partir da aplicação da pesquisa bibliográfica com base na coleta de dados e informações em bases teóricas da literatura acadêmico-científica. Os resultados da pesquisa demonstraram que as micros e pequenas empresas no Brasil utilizam a contabilidade gerencial como uma das principais ferramentas de tomadas de decisão, principalmente com base no suporte das informações estratégicas de gestão de

1 Pós-graduada em Contabilidade, Auditoria e Controladoria pela Faculdade Metropolitana de Manaus (FAMETRO), graduada em Ciências Contábeis pela Universidade Paulista (UNIP). 
mercado. Assim sendo, observa-se que a contabilidade gerencial em micro e pequenas empresas no Brasil possui uma tendência de amplificação no mercado, tendo em vista o seu suporte estratégico para suprir a organização com informações contábeis que otimizem a tomada de decisão.

Palavras-chave: Contabilidade Gerencial, Micros e Pequenas Empresas - Brasil, economia, política.

\section{INTRODUÇÃO}

Desde séculos há um debate que permeia todo o processo de discussão sobre o desenvolvimento de um país: a relação entre a economia, a política e a sociedade. Por muitos anos esse tipo de debate tem sido fortalecido por discussões, estudos e teorias que transformaram todo o modo de vida e de percepção macroeconômica no mundo durante todo esse tempo. Afinal, qual a perspectiva social, política e econômica temos pela frente sob o aspecto da contabilidade?

A contabilidade é uma ciência complexa e multiforme. Tem como objeto de estudar, a partir de um sentido lato da conceituação, analisar e estudar as variações de um patrimônio ou determinado bem com base nos aspectos qualitativos e quantitativos. A característica da contabilidade como prática parte da concepção de que ela é responsável por analisar fenômenos e compreender como eles ocorrem dentro de uma empresa ou organização.

O contexto macroeconômico mundial foi formado por uma série de nuances e ações que ajudaram a construir o que observamos hoje como uma perspectiva de uma nova ordem econômica no mundo. O contexto histórico é crucial para a compreensão das relações comerciais, políticas e sociais estabelecidas durantes os séculos para compreender como a estrutura econômica atual foi concebida.

Os primeiros sistemas de escritura, desde os anos de 1494 em Veneza, na Itália, e logo em seguida com a invenção da imprensa por Guttemberg, foi um período histórico fundamental para o surgimento das primeiras atividades contábeis no mundo. Toda 
contextualização histórica é apresentada por ludicibus (2009) ao relatar que a prática contábil é bem mais antiga que a Era Cristã, tendo em vista que muitos relatos históricos apontam para a realização das primeiras atividades históricas a aproximadamente 4.000 a.C.

O homem primitivo passou a desenvolver as suas relações dentro da sua própria estrutura de comunidade, o que ao passar dos tempos foi sendo intensificado pelo surgimento das primeiras relações comerciais e o consequentemente crescimento de patrimônio e acúmulo de riquezas, como bem observado após a expansão do período mercantilista no século XVI. Toda essa conjunta econômica e macroeconômica desencadeou em uma necessidade latente do homem em desenvolver estratégias para lidar com esse patrimônio.

A necessidade em gerenciar seus bens patrimoniais sempre foi uma preocupação do homem. O acúmulo de riquezas é um dos fatores que iniciou o processo de proliferação do modelo capitalista no mundo, sendo responsável por dinamizar as relações de mercado e ampliar a capacidade de produção dentro dos setores. Toda essa conjuntura, do ponto de vista histórica, demonstra que a contabilidade eclodiu no bojo nas relações humanas, sendo necessária para influenciar as relações econômicas que corroboraram para construir a economia mundial.

O gerenciamento de uma empresa precisa ser focado nas mudanças de mercado e no surgimento de novos modelos de negócio, sendo considerado por muitos especialistas e analistas de mercado como uma tarefa árdua e de grande complexidade. Mota e Cirino (2010) afirmam que uma empresa precisa investir na sua sustentabilidade administrativa, contábil, fiscal e jurídica, de modo que, haja uma correta adequação dos seus padrões de atuação frente ao mercado.

O objetivo desse estudo é analisar as práticas da contabilidade gerencial nas micro e pequenas empresas no Brasil a partir de uma visão holística sob o aspecto das discussões técnicas realizadas no âmbito social, econômico e político dentro do contexto atual. Ademais, Observar a prática da contabilidade gerencial no Brasil sob uma perspectiva histórica, técnica e administrativa e discutir as perspectivas de 
praticidade da contabilidade gerencial adotada pelos gestores nas micro e pequenas empresas brasileiras.

O estudo foi pautado em uma revisão bibliográfica com base nas produções técnicoacadêmicas da área da Contabilidade com enfoque na Contabilidade Gerencial. O objeto do estudo serão as micros e pequenas empresas no Brasil sob a análise das práticas da contabilidade gerencial desenvolvidas por elas como ferramenta de apoio para a tomada de decisões.

A base teórica partiu das análises das obras de ludicibus (2009), Marques (2004), Padoveze (2012) e Sant'anna (2011) e demais estudos técnico-acadêmicos que tratam dos aspectos práticos e administrativos da contabilidade gerencial em micro e pequenas empresas no Brasil.

A contribuição do estudo tem como enfoque a análise holística da prática administrativa e técnico-gerencial da contabilidade gerencial das micro e pequenas empresas brasileiras sob o aspecto da revisão de literatura produzida sobre o tema. O cerne da pesquisa analisa qual a relevância da contabilidade gerencial para micro e pequenas empresas no aporte à tomada de decisões administrativas e técnicas.

Compreende-se que há uma necessidade de aprofundar esses estudos na academia, tendo em vista que a contabilidade gerencial é uma subárea de suma importância para o apoio à atividades estratégicas em empresas: controle administrativo, controle estratégico , controle operacional e controle de custeio e do cliente.

O método de pesquisa realizado para esse estudo partiu da aplicação da pesquisa bibliográfica com base na coleta de dados e informações em bases teóricas da literatura acadêmico-científica.

Pádua (2004) afirma que a pesquisa bibliográfica ou revisão bibliográfica consiste em um tipo de pesquisa que tem por finalidade reunir os principais estudos sobre um determinado tema (livros, artigos científicos, teses, dissertações, anais, dentre outros) a fim de embasar uma argumentação e construir uma análise teórica do estudo. Para o estudo, a coleta das informações será realizada por meio do acesso às fontes 
primárias (bibliografias) das áreas de Contabilidade e Administração, com enfoque na contabilidade gerencial, a fim de discutir e analisar os materiais por meio da revisão de literatura.

A revisão de literatura ou revisão bibliográfica é definida por Flick (2013) como um tipo de estudo que tem como cerne principal a discussão de estudos bibliográficos a partir da tratativa de assuntos ou temas abordados por autores que tratam de uma determinada área. $\mathrm{O}$ instrumento de coleta de dados para o estudo foi a análise bibliográficas técnico-acadêmicas por meio da captação de informações em bases de dados com estudos que discutem a aplicabilidade da contabilidade gerencial, com o objetivo de compreender as suas práticas, influências, diretrizes e ações na conjuntura administrativa nas micro e pequenas no Brasil.

\section{GLOBALIZAÇÃO, DESENVOLVIMENTO ECONÔMICO E AS RELAÇÕES SOCIAIS}

Antes de qualquer abordagem mais aprofundada sobre a globalização e todos os conceitos que permeiam suas definições, conceitos e realidades, é de suma importância observar todas as nuances identitárias que convergem para a construção da globalização como panorama histórico, econômico, político e de mercado até os dias de hoje. Em uma de suas grandes obras, o autor José de Saramago fez uma lúcida e palatável análise sobre o capitalismo e a globalização em sua obra "Ensaio sobre a cegueira" lançado em 1995. Nessa obra o autor faz uma série de abordagens acerca da interdependência dentre as pessoas e a necessidade do ser humano retomar a si a percepção de que o mundo é frágil e carece de conexões.

Observa-se que a obra faz um prelúdio muito auspicioso sobre a relação do homem com a sociedade e os seus conceitos de interdependência. Diante exposto, é salutar analisar que a globalização também parte de uma gênese moldada nas relações e na forma como a sociedade e todo o processo de interdependência que conecta cada pessoa são substanciais e essenciais no ponto de vista social. Hoje, a sociedade é apontada como sendo uma sociedade da informação - ou da interação entre a 
informação e o homem - com base na percepção de que o homem por si só não deve ser observado como objeto em isolamento.

O conceito de conexão pauta a definição da globalização como um processo de encadeamento articulado e cíclico - como bem observa Campos e Canavezes (2007, p.4):

A noção de globalização surge, pois, a propósito de vários domínios da nossa vida e encontra expressão em todas as grandes línguas do mundo. Apesar de muito recorrente (e talvez também por isso) a noção de globalização nem sempre é clara, prestando-se a usos e sentidos muito diversos. É, pois, importante clarificar a noção de Globalização. Um bom ponto de partida é atentarmos-nos diferentes discursos, aproximações e definições de globalização - oriundas não só do mundo acadêmico, mas também de organizações internacionais como a OIT e do mundo sindical. Deste modo, não fechamos a nossa visão sobre o fenômeno e podemos enriquecer a nossa noção com visões que, sendo diferentes, não são exclusivas, nem são necessariamente contraditórias entre si, podendo mesmo ser complementares e, sobretudo, convocam a debate diferentes dimensões e perspectivas sobre a Globalização.

Para entender a globalização é de suma importância analisar todos os processos que estão relacionados dentro da sua estrutura de formação histórico-social. Todo o processo que permeia a globalização está relacionado ao conceito de integralização econômica, política, cultural e social - de modo que o seu panorama represente uma nova visão de sociedade com base na integração -- não no isolamento (Figura 1):

Figura 1 - Globalização

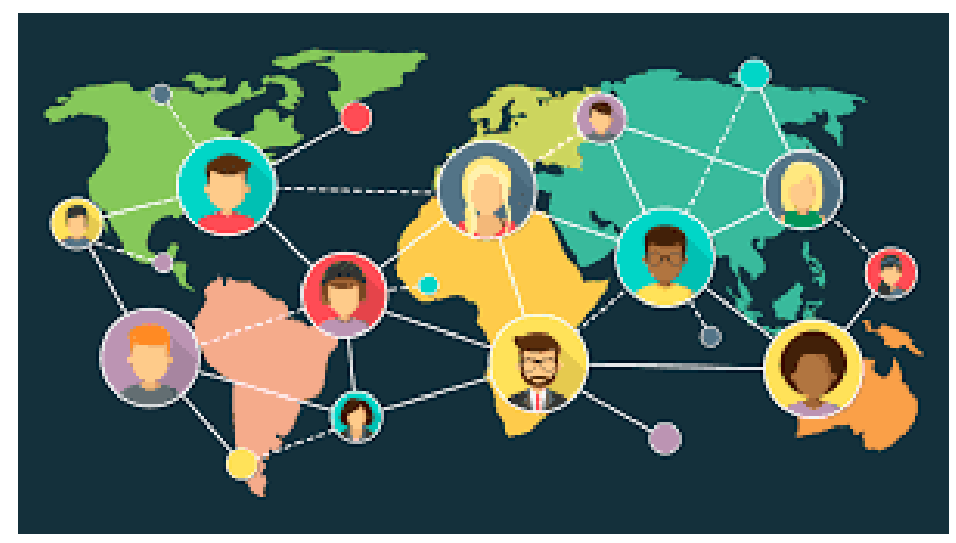

Fonte: Campos e Canavezes (2007) 
O conceito que permeia a discussão sobre a globalização pode ser observado dentro das principais áreas do conhecimento: Ciências Sociais Aplicadas, Engenharia, Direito, Administração, Contabilidade, Filosofia, Sociologia, História, dentre outras áreas. As relações apresentadas sobre a globalização podem ser resumidas na concepção do conceito de integração entre as pessoas dentro de um contexto socioespacial. Por conseguinte, se faz necessário alinhar o pensamento sobre o tema dentro do prisma de análise de alguns estudiosos discute sobre a globalização e suas implicações nos mais diversos campos da sociedade.

Murteira (1997) trata da globalização a partir da concepção de materialização do mercado e da economia em escala global. A análise sobre a globalização dentro do prisma econômica está envolta em uma discussão sobre o papel da sociedade dentro do crescimento das relações de mercado e da explosão capitalista. As transformações geradas pela globalização funcionam como uma motriz de reconfiguração da cadeia de relação: econômica, social de mercado. A redefinição espacial, por exemplo, como mercado e pelo crescimento da necessidade da população em manter essa relação em todo tempo.

A globalização deve ser observada como um processo de transformação, logo, ela é dinâmica e funciona com base em um sistema de cadeia. $O$ fato dela está em constante evolução é uma das características de maior representação da sua atuação em um país, por exemplo. A velocidade com que a comunicação é observada hoje, por exemplo, é totalmente diferente de como a comunicação era realizada em décadas atrás. Muteria (1997) analisa que a velocidade no processo de mudanças sociais foi impulsionada, principalmente, pela globalização e por suas forças atuantes: tecnologia, informação e a comunicação - todas funcionando de forma integrada e relacional.

Dentro do aspecto do capital e do aprofundamento do conceito de mercado nas interelações advindas com a globalização, Chesnais (1996) apresenta em sua obra o conceito de mundialização do capital. Afinal, o que é a mundialização do capital? Chesnais (1996) discursa que a globalização é uma força propulsora que aprofundou as relações de mercado e o capitalismo como modelo econômico no mundo. Após a 
crise de 1929 o mundo passou por uma transformação em cadeia com o aprofundamento da crise econômica nos países do $1^{\circ}$ mundo - dentro desse contexto, o crescimento do capital eclodiu a partir da necessidade do mercado em se reposicionar perante a crise econômica.

A aceleração do processo de fluidez de capital no mundo foi importante para o desenvolvimento de novas relações comerciais e o crescimento de setores econômicos de grande importância estratégica, tais como o setor da tecnologia e o setor de serviços. Chesnais (1996) apresentou que a globalização foi responsável pelo processo de ressignificação do posicionamento do mercado no pós-crise, sendo crucial para que países considerados como grandes potências retomassem o seu processo de crescimento econômico.

Com base na percepção histórico-geográfica, Santos (2000) observa na obra "Por uma outra globalização" que a globalização, apesar da sua importância estratégica para o mercado global, também foi responsável pelo aprofundamento das diferenças sociais. Esse debate sobre o contexto social do mercado embate na discussão sobre as consequências do capitalismo na sociedade e como as suas consequências podem gerar máculas sociais: pobreza, miséria, desigualdade social, ausência de distribuição de renda, etc. Santos (2000) faz uma análise socioeconômica do processo de acentuação da globalização na década de 80 e 90, observando as transformações sociais e culturais ocorridas a partir das mudanças na cultura e na remodelação dos espaços sociais.

O avanço da globalização é um elemento que contrastou com o crescimento dos bolsões de miséria e da desigualdade social em diversos países no mundo, inclusive os países de $1^{\circ}$ mundo. Santos (2000) analisa que as transformações socioespaciais intensificadas com a globalização permitiu com que houvesse uma ressignificação do espaço a partir do conceito de mercado, ou seja, o mercado passou a ditar as tendências com base na teoria do consumo e no processo de massificação das zonas de produção. Diante de todo esse crescimento econômico em nível global, o aumento da pobreza e da miséria também foi intensificado no mesmo nível de proporção, onde Santos (2000) argumenta que a necessidade de consumo e a preocupação com o 
lucro tornaram a cadeia de relações sociais cada vez mais afastadas e ditadas pelas regras do capital.

Figura 2 - Globalização e a desigualdade social
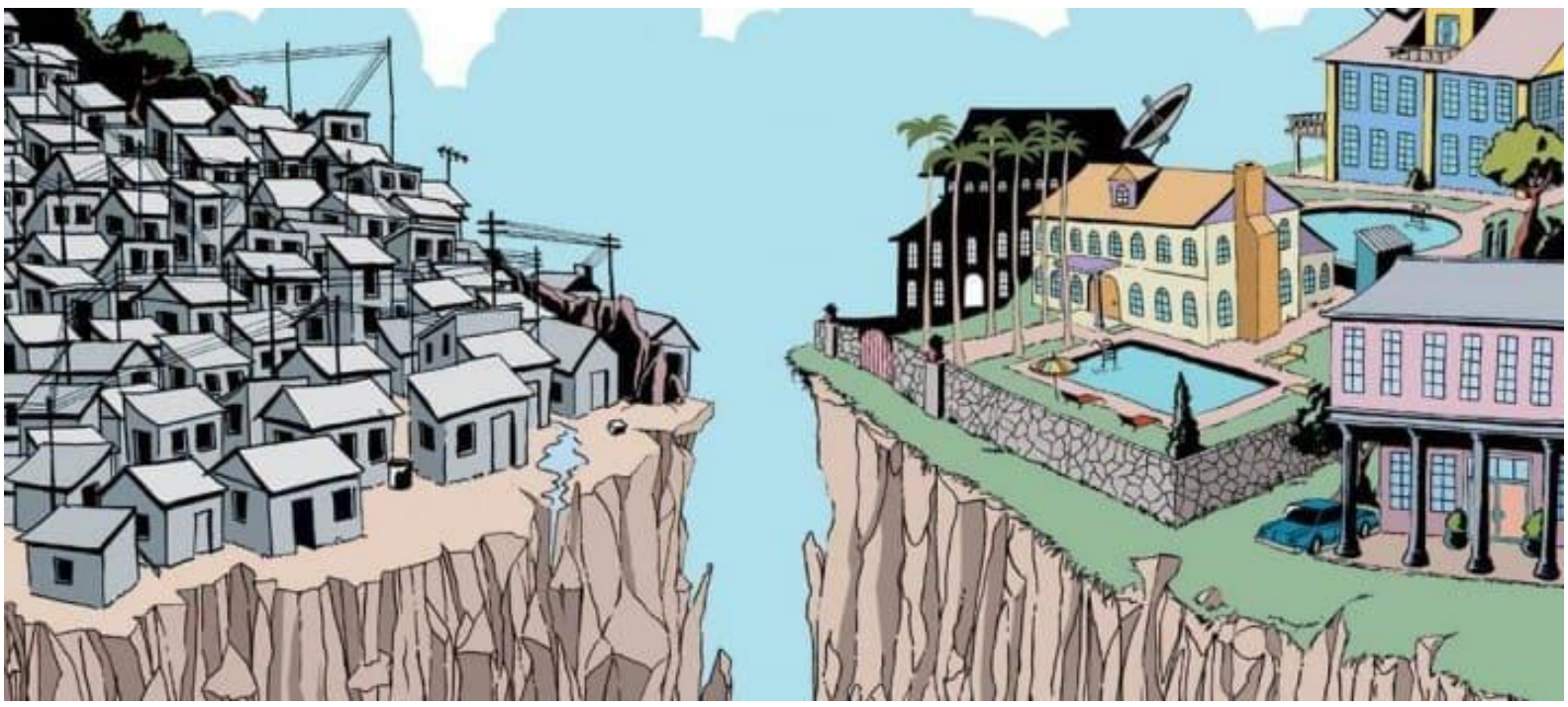

Fonte: Santos (2005)

A desigualdade social e a globalização são temas que constantemente são envolvidos em estudos sobre a relação da economia e o impacto social nos processos urbanos e de conjuntura social:

A globalização implica, obviamente, em que a desigualdade entre a humanidade global esteja recebendo mais atenção. Somente com o desenvolvimentismo pós-Segunda Guerra Mundial, a desigualdade entre as nações do mundo recebeu atenção pública. A atual onda de globalização está provocando a comparação entre outras categorias humanas, como as mulheres do mundo, as crianças do mundo, domicílios em todo planeta (THERBORN, 2011, p.132)

Therborn (2011) argumenta em seu estudo sobre a relação da desigualdade social com a globalização e como o aprofundamento do capital refletiu na sociedade um panorama de maior diferenciação entre as classes sociais. A questão da diversidade é tratada pela globalização como um tema que diverge da razão de proporção no sentido do consumo e do pertencimento, ao ponto de que a perspectiva social parte da desigualdade em todos os seus principais aspectos sociais: cultural, educacional, habitacional, dentre outros. Sobre os aspectos sociais que contrastam com as 
evoluções observadas pela globalização, Therborn (2011) faz um paralelo entre as relações socioespaciais: enquanto na globalização ela é intensificada sob o ponto de vista do mercado, no aspecto social há um deslocamento ainda maior devido a intensificação do capital em face ao aumento da desigualdade social nas camadas sociais menos favorecidas.

\section{POLÍTICA, SOCIEDADE E A PRÁTICA CONTÁBIL}

A relação entre a política e o aspecto econômico está diretamente relacionada com o desenvolvimento social. Para analisar o contexto da contabilidade gerencial, como esta sendo exposta nessa obra, é de suma importância compreender os aspectos que convergem para a prática contábil em pequenas e micro empresas dentro de uma amplitude mais abrangente do mercado externo e interno.

A questão política envolve a sociedade por meio do seu contexto de relacionamento entre o desenvolvimento social e econômico, sendo diretamente responsável por dirimir as ações que serão responsáveis pelas tomadas de decisões no âmbito governamental e público. Nunes Junior (2001) apresenta em sua obra uma visão macropolítica sobre a soberania e a noção de mercado no contexto social, distinguindo dois aspectos: políticas econômicas de interesse público $\mathrm{x}$ políticas econômicas de interesse governamental.

Quanto às políticas econômicas de interesse público é interessante observar que esse tipo de cenário estabelece uma corelação de diversos fatores: sociedade, políticas públicas e recursos públicos. Nunes Junior (2001) argumenta que esse aspecto aglutina áreas e subáreas da sociedade que são interdependentes. Observa-se que uma política de interesse público envolve a natureza coletiva e todos os processos que influenciam o bem estar social e a qualidade de vida da população: saneamento básico, educação, segurança pública, moradia. Esse tipo de contexto é permeado pela gestão de recursos públicos e pela política governamental - bem abordado por Nunes Junior (2001) ao frisar que o planejamento econômico de interesse público deve ser analisado com base nas legislações e regulamentações. 
Quanto às políticas públicas de interesse governamental há de observar os fatores coinfluentes que circundam a gestão pública e a gestão privada: a política governamental. Nunes Junior (2001) analisa que o conceito de soberania faz parte de uma visão macro de proteção dos bens de produção e das garantias e interesses de uma nação, com base em sua política de influência, regida pela sua gestão governamental. Para o interesse privado a relação com a gestão governamental é importante para estender os modos de atividades e ações no cenário micro e macroeconômico.

O desenvolvimento das relações e dos processos de dominação e estruturação de poder em nível global é estabelecido pela política dentro do contexto social. Para entender os conceitos e os cenários econômicos, se faz necessário analisar os moldes onde a sociedade contemporâneo foi construída nos últimos anos. No estudo de Gambarro (2001) sobre a globalização das economias o autor observa o processo de formação das organizações políticas, organizacionais e sociais no Brasil e no mundo sobre o prisma argumentativo da globalização em cadeia. Essa análise, particularmente, faz observamos que o desenvolvimento da política na sociedade está diretamente relacionada com o individuo e com a economia, seja ela local (microeconômica) ou global (macroeconômica).

A globalização trouxe uma roupagem de caracterização do papel da política no individuo e dentro de todo o contexto social. Em outra abordagem, Hobsbawn (2004) analisa que a globalização e a política dentro do contexto da vida do individuo permitiu com que a sociedade como um todo ultrapasse as barreiras impostas por relações comerciais anteriormente estabelecidas, de cunho mais restritivo e isolado, como até os anos 70 e 80 com a política de mercado protecionista em alta na Europa e em grande parte da Ásia. Essa diferenciação entre o protecionismo e a globalização permite observar a sociedade como um conjunto de rédeas globais que passaram a funcionar de forma sincronizada e interligada, ditada pelos princípios políticos e pelas regras do mercado global.

A universalização dos meios de comunicação e o desenvolvimento da economia nos países emergentes também influenciaram para a expansão do conceito de política 
econômica internacional. Hobsbawn (2004) caracteriza a política internacional dos anos 2000 como um grande pilar na amplificação da relação comercial no mundo. A relação do crescimento da política internacional em países do 3ํㅡ mundo, por exemplo, transformou todo o cenário macroeconômico mundial em um panorama de estabelecimento de vínculos e acordos de livre comércio, caracterizados por modelos que foram formados baseados na própria política internacional e dentro dos preceitos difundidos pela globalização.

O contexto social da compreensão da política como instrumento de globalização e ampliação das relações econômicas entre as nações permite observar que as transformações ocorreram com base na participação da sociedade nos debates políticos. Neto e Braz (2006, p.34) analisam dois contextos sobre a economia e a política dentro da concepção da sociedade e dos direitos sociais e trabalhistas no mundo contemporâneo:

A Economia vai se desenvolver no sentido de uma disciplina científica estritamente especializada, depurando-se de preocupações históricas, sociais e políticas. Tais preocupações serão postas à conta das outras ciências sociais que se articulam na sequência de 1848: a História, a Sociologia e a Teoria (ou Ciência) Política. No marco dessa "divisão intelectual do trabalho científico", a Economia se especializa, institucionaliza-se como disciplina particular, específica, marcadamente técnica, que ganha estatuto científico-acadêmico. Adequada à ordem social da burguesia conservadora, torna-se basicamente instrumental e desenvolve um enorme arsenal técnico (valendo-se intensivamente de modelos matemáticos). Ela renuncia a qualquer pretensão de fornecer as bases para a compreensão do conjunto da vida social e, principalmente, deixa de lado procedimentos analíticos que partem da produção - analisa preferencialmente a superfície imediata da vida econômica (os fenômenos da circulação), privilegiando o estudo da distribuição dos bens produzidos entre os agentes econômicos e quando, excepcionalmente, atenta para a produção, aborda-a de modo a ladear a teoria do valor-trabalho.

Para entender o contexto da economia como ciência social e política são de suma importância compreender que as suas relações sociais são bem mais estreitas e não descoladas da realidade do surgimento da política como instrumento de governança pública. Neto e Braz (2006, p.34) também observam que a relação da ciência 
econômica com a economia política surgiu a partir das transformações sociais e culturais:

A constituição dessa "ciência econômica" marca uma verdadeira ruptura em face da Economia Política clássica. Desta, ela herdou uma característica: a consideração das categorias econômicas próprias do regime burguês como realidades supra-históricas, eternas, que não devem ser objeto de transformação estrutural, senão ao preço da destruição da "ordem social"; assim, para essa "ciência econômica", propriedade privada, capital, salário, lucro etc. fazem parte, natural e necessariamente, de qualquer forma de organização social "normal", "civilizada", e devem sempre ser preservados. Mas a "ciência econômica" abandonou resolutamente as ideias que, formuladas pela Economia Política clássica, poderiam constituir elementos de crítica ao regime burguês (por exemplo, a teoria do valor-trabalho, que foi substituída pela teoria da "utilidade marginal") e, com esse procedimento de princípio, tornou-se um importante instrumento de administração, manipulação e legitimação da ordem comandada pela burguesia.

A crítica da econômica política realizada por Karl Marx (1818-1883) apresenta uma face mais revolucionária da compreensão do capital e do crescimento do capitalismo dentro da influência econômica e social no mundo vivenciado durante o século XIX (Figura 4). Ademais, as ideias desenvolvidas para revolução do proletariado partiram da critica ao sistema capitalista e ao processo de acumulo de capital - tendo como pano de fundo a situação operária e o modo de vida do trabalhador. Mais a frente, após o aprofundamento da globalização, a política e a sociedade passou a seguir em linha tênue e retilínea com enfoque cada vez mais próximo ao mercado. 
Figura 4 - Relações de trabalho e o capital

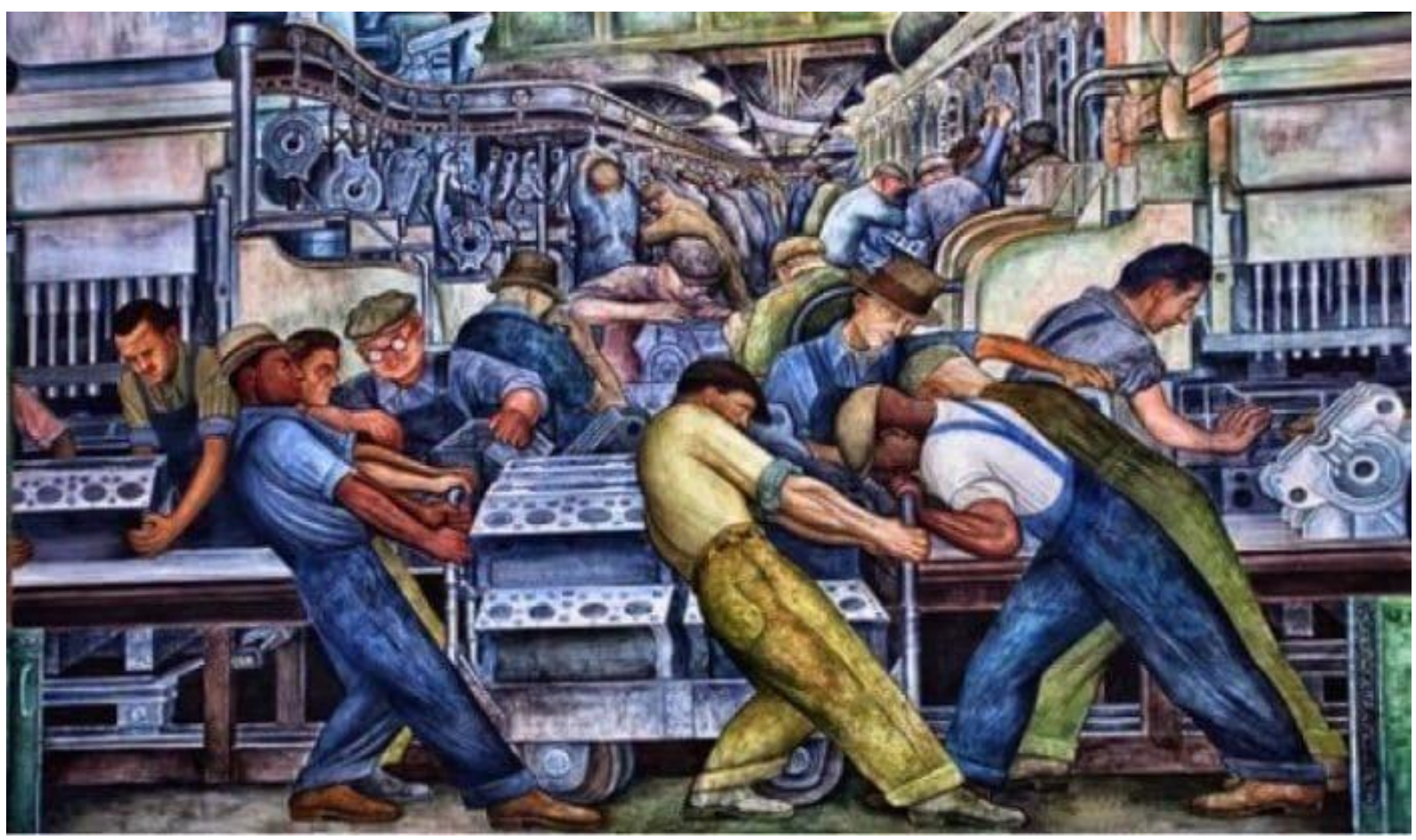

Fonte: Adaptado de Diário da Liberdade (2011)

A participação política na globalização é reflexo de um processo de formação traída pelos novos conceitos de mercado e pelo aprofundamento das questões sociais aplicadas as relações entre a sociedade e o capital. Neto e Braz (2006) analisam que o contexto histórico-social observado desde o século XVIII com a Revolução Industrial apresenta uma transformação gradual da sociedade com a inserção do individuo como objeto de frequente participação nas decisões políticas e no processo de construção das decisões institucionais. Com a globalização, esse processo de construção foi intensificado pela ampliação de atuação dos nichos sociais nas mudanças observadas na economia e no mercado global.

A política econômica brasileira, dentro do seu contexto histórico, é apresentada por uma série de fatos históricos que apresentam o país em todos os seus contextos econômicos: do desenvolvimentismo até as atuais políticas de economia externa. Diante exposto, é de fundamental importância analisar que a política economia no Brasil sempre teve no seu bojo de expansão a busca pela industrialização e pelo investimento no setor empresarial. Paula e Pires (2017) fazem uma análise bastante 
encorpada da política brasileira dentro do contexto econômica: da Nova República até os dias de hoje, passando pela política desenvolvimentista nos anos 50 e 60 até a reestruturação observada nos anos 2000.

O processo de desenvolvimento das empresas dentro do contexto político no Brasil sempre foi presente. O impulsionamento econômico foi realizado pelo investimento em indústrias e motivou a aceleração da economia e a expansão do capital urbano, construindo um Brasil cada vez mais produtivo em setores estratégicos. Essa percepção histórica é apresentada por Paula e Pires (2017) ao observarem que as empresas no Brasil estão entrelaçadas no contexto de desenvolvimento do país, principalmente o setor de serviços e a indústria.

As mudanças econômicas possibilitaram ao longo do tempo que as empresas adequassem a sua produção a realidade do país. Dentro desse sentido, as empresas passaram a desenvolver estratégias de fortalecimento da capacidade produtiva, tendo como pano de fundo o desenvolvimento social e a ampliação do mercado para o cenário mundial. Santos (2000) observa que a globalização dentro da política economia fortaleceu as empresas e, principalmente, as empresas conglomeradas que são as empresas de maior capacidade estratégica e com maior poder de capital.

A relação das empresas conglomeradas com a política econômica no Brasil e na América Latina possibilitou que o mercado interno e externo fosse redesenhado com base no poder do capital e na estratégia de expansão de serviços e produtos em todo o cenário mundial. Neto e Braz (2006) observam que o aprofundamento e a intensificação do capital na sociedade são reflexos de uma sociedade cada vez mais consumista, o que emerge em um cenário bem mais alinhado ao que Mark afirmando em sua obra "O Capital" ao dizer que o consumo é a raiz do capital.

O cenário de expansão do mercado interno e externo possibilitou a aproximação do mercado com as próprias relações comerciais, impulsionadas principalmente pela globalização nas atividades comerciais e a necessidade de gestão do patrimônio. ludícibus e Oliveira (2003) observam que a contabilidade é uma área altamente estratégica para a aproximação das relações do mercado, das empresas e da 
sociedade dentro do processo de crescimento do capital. Tendo em vista que a economia é fundamental na sociedade, a prática contábil é um elo importante e necessário para estabelecer o papel de estruturar financeiramente as organizações e possibilitar que a gestão do seu patrimônio seja realizada de forma eficaz e rentável.

A relação da globalização e da contabilidade é inerente, do ponto de visa do crescimento das relações de mercado (aprofundamento no acumulo de riquezas) e a gestão inteligente do capital. ludícibus e Oliveira (2003) argumentam que o avanço da contabilidade no mundo moderno, desde o inicio do avanço da globalização no mundo, tem sido fundamental para manter todo o processo econômico estável em muitas empresas. Essa afirmação vai de encontro a compreensão de que a importância da contabilidade como ciência estratégica na gestão patrimonial é bastante relevante para a sobrevivência de empresas e de negócios realizados em todo tempo.

Possas (2002) faz uma análise da relação do desenvolvimento econômico dentro do prisma macro e microeconômico do ponto de vista da relação da prática contábil com a globalização. Dentro desse aspecto, a globalização promove a interação do capital com a sociedade e desencadeia ações que emergem na relação direta com o individuo, desde a criação de novos produtos por meio da possibilidade do aprofundamento de capital, até a necessidade de abrir o seu próprio negócio ou entrar no mercado de trabalho.

\section{A GESTÃO EMPRESARIAL E A CONTABILIDADE}

Para compreender a relação das empresas e pequenas no Brasil (MPE's) dentro contexto micro e macroeconomia é fundamental compreender a gestão empresarial e as suas nuances dentro da relação com a sociedade e com o desenvolvimento econômico e contábil. Em capítulos anteriores já foi abordado a globalização, a sociedade e a política dentro do contexto plural da formação econômica do Brasil nesse capítulo será apresentado a gestão empresarial e como o conceito da empresa e do capital está relacionado com a prática da contabilidade. 
Cordeiro e Ribeiro (2002) apresentam uma breve abordagem sobre o contexto histórico-econômico da gestão empresarial no contexto nacional:

A partir da década de 1990 o ambiente de negócios se tornou mais complexos fenômenos econômicos e sociais de alcance mundial estão reestruturando o ambiente empresarial. a globalizado da economia, alavancada pela tecnologia da informação e da comunicação, é uma realidade inescapável. As chamadas novas tecnologias, bem como as novas formas de organização do trabalho, têm colocado os métodos tradicionais de gestão das empresas no banco dos réus (CORDEIRO; RIBEIRO, 2002, p.1)

Compreende-se então a gestão da empresa está relacionado diretamente com instrumentalização de ações que decidirão sobre a sobrevivência da empresa em todos os seus aspectos: recursos humanos, recursos financeiros, mudanças, cenários, relação com o mercado, investimentos, planejamento, dentre outros. Cordeiro e Ribeiro (2002) observam que a gestão envolve bem mais do que o planejamento de sobrevivência, eles observam que a necessidade de permanecer ativo no mercado é resultado de uma sinergia permanente e, acima de tudo, consistente.

Martinello (2011) afirma que a gestão empresarial é um conjunto sistêmico de ações que convergem para um bem comum: o planejamento e controle de uma empresa. De tal modo, a gestão como fator de ação não deve ser compreendida como um ato isolado, ou seja, precisa haver uma relação harmônica entre os objetivos e as metas de uma organização de acordo com as necessidades e o cumprimento funcional dessa empresa. Essa concepção parte do pensamento apresentado por Chiavenato (2000) que analisa a gestão empresarial como um elo administrativo entre a vontade do gestor e a capacidade de juntar e fazer funcionar todo o sistema da empresa em prol de um caminho unívoco. 
Figura 5 - Gestão empresarial e a prática contábil: como alinhar?

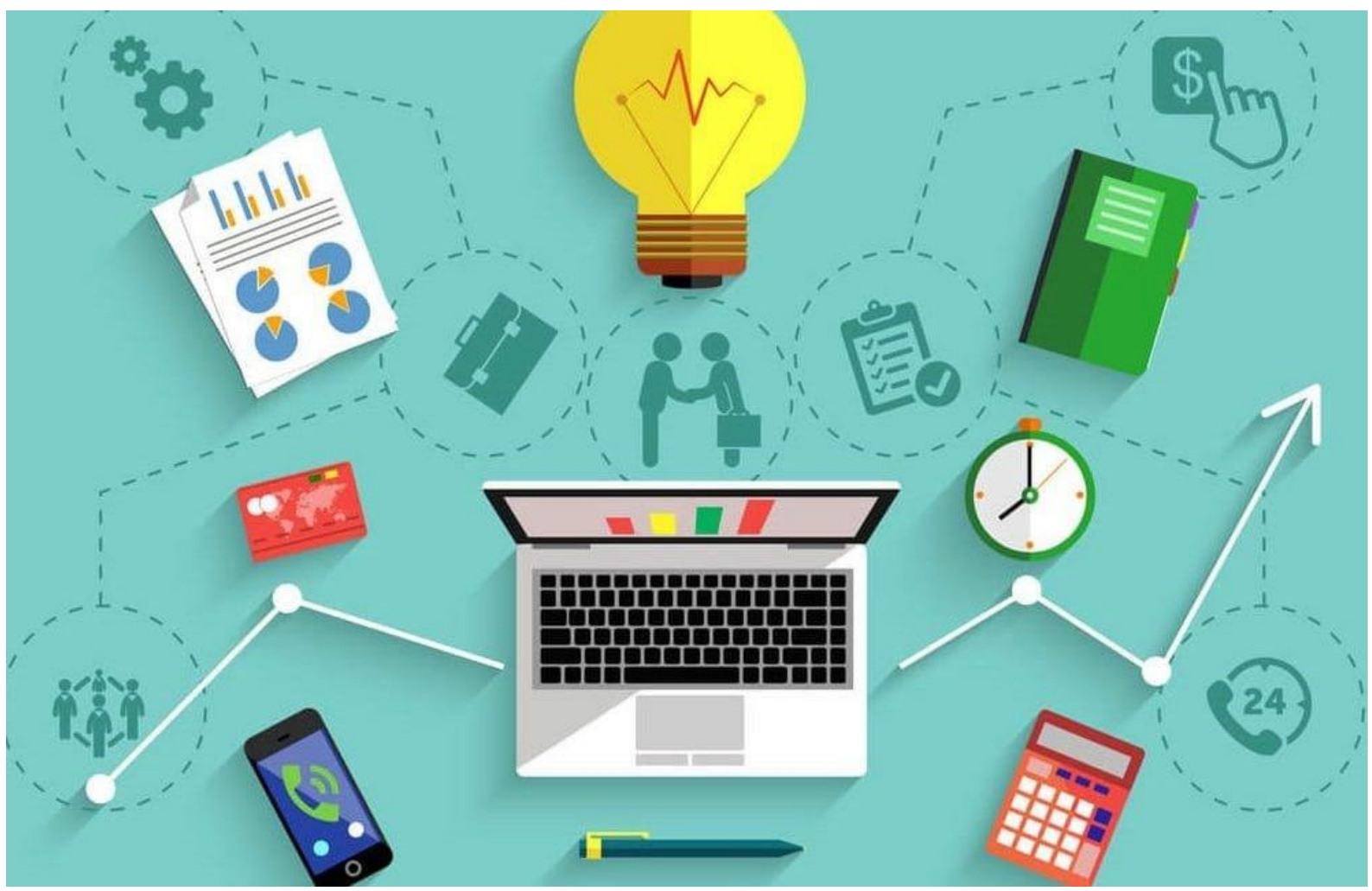

Fonte: Novo Negócio (2018)

Mas afinal, qual o papel da gestão empresarial dentro do contexto da contabilidade em uma empresa? Cinco passos são observados para o desenvolvimento da prática gerencial em simbiose com a contabilidade. Elas podem ser observadas como:

\section{Capacidade de gerir recursos}

A gestão dos recursos é uma ferramenta de gestão primordial para garantir com que o patrimônio da empresa seja devidamente controlado e gerido de forma eficaz. A contabilidade traz para a gestão da empresa um olhar mais holístico e multifacetado sobre o próprio planejamento estratégico: investimento de capital, ampliação da rede de negócios, metas e objetivos a longo prazo, dentre outros. Importante analisar que a gestão de recursos é um caminho ideal para que qualquer empresa consiga expandir sua atuação e os seus negócios em meio a um cenário competitivo.

2. Investimentos 
A capacidade de investir e ampliar os negócios da empresa é um passo que deve ser dado de forma estratégica e com um olhar sistêmico e atuante sobre o mercado. A contabilidade gerencial, por exemplo, oferece a empresa uma análise bem mais acurada de qual medida tomar e em qual tempo investir ou controlar o seu patrimônio. As empresas conseguem, por meio de uma gestão contábil eficaz, analisar quais áreas de atuação ela deve tomar decisões, a depender da situação que ela se encontra e do momento atual do mercado.

\section{Ampliar os nichos de atuação}

Toda empresa visa expandir os seus negócios por meio do aumento dos investimentos para conseguir ampliar sua atuação em uma determinada territorialidade. Além da expansão física, as empresas estão investindo também na expansão tecnológica por meio da atuação nas redes sociais e no desenvolvimento da sua marca na internet. Esse tipo de expansão também pode ser observado por meio de uma gestão empresarial estratégica alinhad a prática contábil gerencial eficiente, de modo que a percepção de quando e de como expandir permite que o gestor consiga observar o time do mercado e amplie seu nicho de investimento.

\section{Capacidade produtiva}

Quando é abordado o controle patrimonial é de suma importância que haja um olhar estratégico para o controle dos gastos e de como a balança de investimentos deve ser operada de maneira gradual, cautelosa e com base na medição do mercado. Uma análise contábil sobre o patrimônio da empresa e toda a estrutura que envolve os bens patrimoniais e os recursos dispostos na empresa propicia que a empresa tome a atitude mais acertada. Ao abordar a tomada de decisão, Chiavenato (2000) observa que uma decisão do gestor deve ser acompanhada de uma boa análise interna e externa, logo, é fundamental que todas as ferramentas de apoiam sejam suficientemente disponibilizadas para que não seja realizada nenhuma ação incongruente com o planejamento estratégico anteriormente estabelecido.

5. Desenvolvimento patrimonial 
As pequenas e médias empresas, bem como as grandes empresas e conglomerados, tem como um de seus objetivos principais a expansão do seu negócio por meio da ampliação dos seus nichos de atuação (filiais) além do aumento da capacidade produtiva. O investimento em uma gestão contábil inteligente é capaz de apresentar um modelo de negócio mais transparente e eficiente, tendo em vista que o investimento de capital precisa ser realizado dentro de um planejamento muito bem traçado e previamente observado pela equipe contábil da empresa. $O$ ato de gerir vai além de desenvolver estratégias, ela está diretamente relacionada com o desenvolvimento das ações a longo prazo por meio dos resultados - ou seja - uma empresa que não apresenta resultados no desenvolvimento do seu patrimônio (lucro) está enfrentando algum problema no seu planejamento.

Figura 6 - Qual o papel da contabilidade na gestão empresarial?

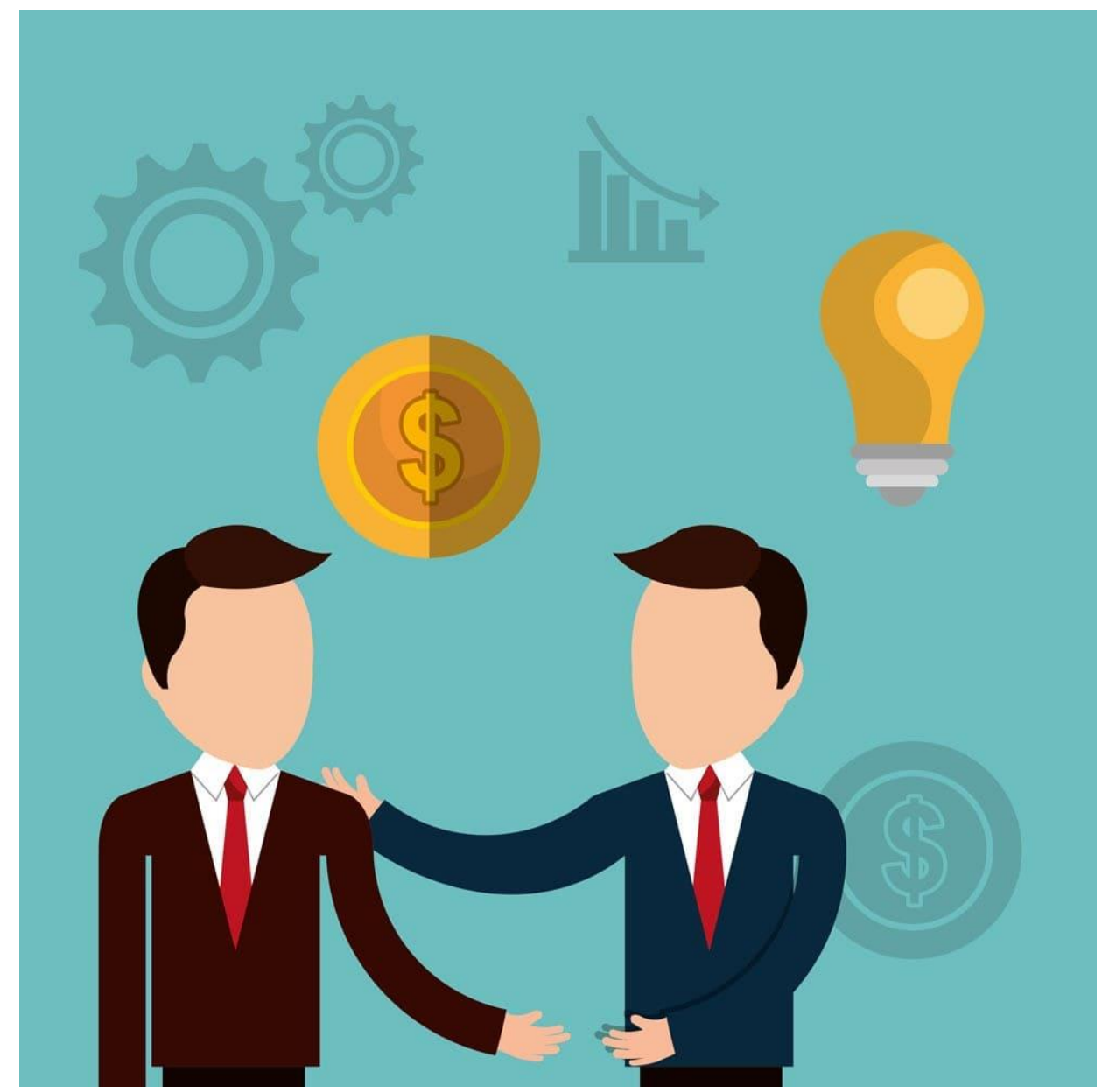

Fonte: Novo Negócio (2018) 
O papel do contador na relação empresarial pode ser observado como um fator que agrega para o desenvolvimento da empresa. Ele pode atuar em áreas específicas e estratégicas que vão além apenas da prática contábil tradicional, dando suporte técnico, operacional e gerencial nas tomadas de decisões sobre investimentos a longo prazo e , principalmente, na organização do planejamento estratégico da empresa.

A gestão empresarial é uma forma de gestão que busca, de forma holística, garantir que a empresa permaneça em uma linha direta e objetiva que atenda aos objetivos, a missão e aos valores estabelecidos no seu plano de atuação (ALMEIDA, 2001). Entende-se então que o modus operandi da gestão empresarial está atrelada ao surgimento de possibilidades que sustentem as ações estabelecidas pela empresa.

Costa e Yoshitake (2004) afirmam que no Brasil, nos anos 90 e inicio dos anos 2000, as empresas ainda investiam pouco em planejamento empresarial, sobretudo, no setor contábil e fiscal. Muitas empresas do exterior iniciaram desde os anos 80 a prática de investimento em análises econômicas e contábeis com o propósito de sustentar o seu planejamento estratégico e subsidiá-los de informações pertinentes frente aos novos padrões do mercado. Diante desse cenário de transformações, as empresas brasileiras passaram a retomar o ganho de espaço com os acordos comerciais e a ampliação do negócio em alguns ramos estratégicos: Agronegócio, Tecnologia, Serviços e Indústria automobilística.

É interessante observar que a colocação estratégica de crescimento das empresas no Brasil tem sido caracterizada pela diversificação com base na cadeia produtiva. Segundo dados do MundoGeo, em 2018, o crescimento das empresas de pequeno e médio porte no Brasil correspondeu a uma fatia de 35\% (em média) do lucro anual da produção interna do país. Esses dados correspondem a uma realizada já observada em tempos de gestão maximizada de acordo com a produção em cadeia, atingindo a um mercado externo de forma mais rápida. 
Figura 7 - Expansão da cadeia produtiva no Brasil (2017-2018)

\section{Cadeia}

\section{PRODUTIVA}

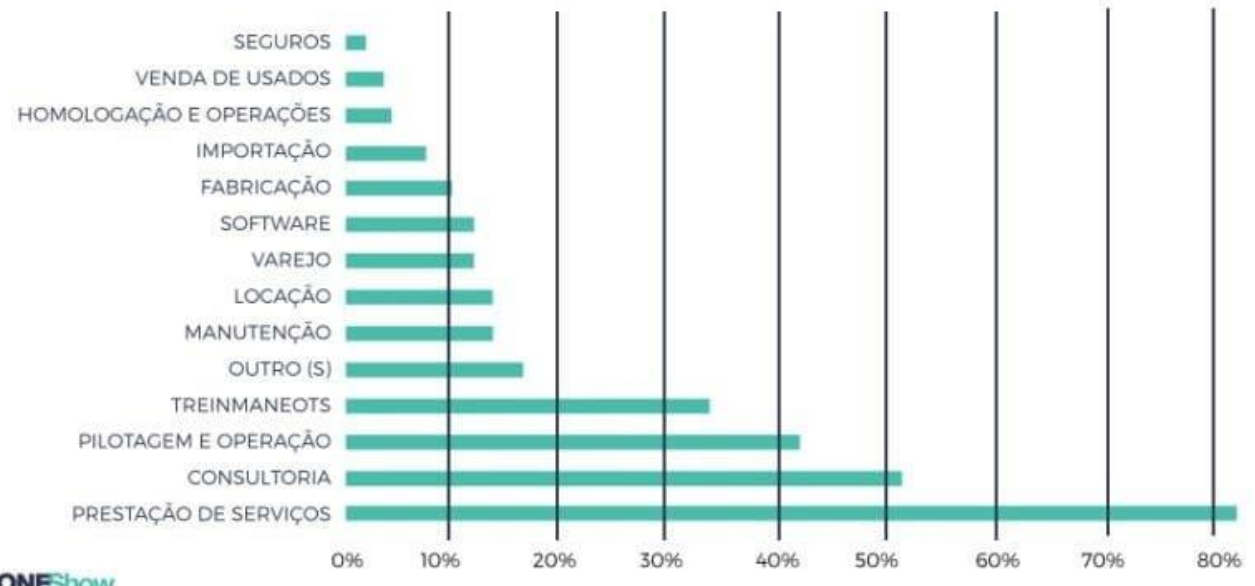

MundoGEO DRONEShow

Fonte: MundoGeo (2018)

O crescimento da economia em zonas no Brasil vem permitindo com que a cadeia de produção atinja a um nível de expansão não observado em décadas anteriores. Observa-se que $50 \%$ do nicho de mercado que obteve um crescimento em até $40 \%$ nos anos de 2017 e 2018, de acordo com o gráfico acima, estão diretamente ligadas ao setor de prestação de serviços e de tecnologia. Dentro desse cenário, a contabilidade gerencial é de fundamental importância para gerir os bens patrimônios e todo o recursos financeiro gerado a partir desse crescimento, de forma estratégica e baseado em um planejamento a longo prazo.

\section{CONTABILIDADE GERENCIAL: PRINCIPIOS E CONCEITOS}

Entende-se por contabilidade gerencial a produção útil de informação para a administração com base em informações estratégicas que auxiliem no planejamento, na medição, avaliação e tomada de decisões na organização com base nessas análises (IUDíCIBUS, 2009). 
Outro conceito sobre contabilidade gerencial é apresentada por Pizzolato (2000) que define como uma tipologia da contabilidade cujo enfoque está direcionado a identificação, mensuração e sistematização das informações do mercado para apoiar o gerenciamento sobre a realidade econômica da empresa.

Com vista ao desenvolvimento de ações de melhoria apresentados no planejamento estratégico, pode ser observada como uma estratégia de gestão crucial para qualquer empresa que busca a solidez no mercado e vantagens competitivas. Caneca et al (2009) observa que as empresas de pequeno porte possuem um papel fundamental no cenário econômico atual, visto que elas são geradoras de emprego e renda.

Em uma análise mais direcionada a Contabilidade, Batista et al (2012) constatou em sua pesquisa que grande parte das empresas, principalmente as de pequeno porte, encerram as suas atividades devido a uma má gestão contábil. Essa informação mostra que os serviços prestados por contadores influenciam diretamente na estrutura de gestão de uma empresa.

Assim sendo, compreende-se que a contabilidade gerencial lida com todo o arcabouço de informações que buscam dar suporte ao gestor na tomada de decisões. Horngren; Sundem e Stratton (2004) enfatizam os principais aspectos que formam a estrutura de desenvolvimento na contabilidade gerencial: mensuração, análise, interpretação dos dados, identificação das informações, elaboração dos dados e suporte ao gestor.

Um dos aspectos da contabilidade gerencial é acoplar todos os demais instrumentos da contabilidade e assim estruturar o planejamento financeiro e organizacional da empresa. Padoveze (2012) afirma que a contabilidade gerencial permite uma análise mais holística acerca análise financeira e gerencial de uma organização. Ela é composta de técnicas e procedimentos contábeis que corroboram para uma análise financeira mais acurada e auxiliar os gerentes das unidades em seus processos decisórios.

Crepaldi (2006) analisa que a contabilidade gerencial tem como base o fornecimento de instrumentos administrativos e técnicos que permitem ao gestor analisar, de forma 
holística, todo o funcionamento contábil da organização com base em informações. Esse processo de coleta e sistematização das informações garante que a empresa estruture seus planos contáveis e traduza esses dados de acordo com as análises realizadas na gestão contábil.

O planejamento estratégico, que é a sistematização das estratégias e ações com foco na garantia de melhorias ao longo prazo, está diretamente ligada com a contabilidade gerencial. O controle de todas as atividades financeiras de uma empresa precisa está alinhado ao planejamento estratégico, por isso, a contabilidade gerencial garante com que o planejamento contábil da empresa seja sustentável (VICO MAÑAS, 2012).

Crepaldi (2011) faz uma análise sobre a relação da contabilidade gerencial com a gestão empresarial Entende-se como gestão empresarial a sistematização de informações estratégicas para apoiar uma tomada de decisões, logo, a contabilidade gerencial faz parte de um modelo sistemático que visa apoiar, no âmbito financeiro e econômico, medidas e ações que garantam que esse processo seja embasado em um conhecimento acurado.

A contabilidade gerencial como instrumento de gestão atinge sistematicamente as principais áreas e objetivos de uma organização: vendas, redução de custos, controle de estoque, controle de gastos, investimentos em inovação, dentre outros. Atkinson (2008) argumenta que a contabilidade gerencial garante que a empresa consiga ter uma visão mais holística da sua saúde financeira, ou seja, ela subsidia informações sistêmicas sobre aspectos que compõem a estrutura organizacional.

\section{MICROS E PEQUENAS EMPRESAS NO BRASIL (MPES)}

As micros e pequenas empresas (MPEs) recebem tratamento jurídico diferenciado e possuem características distintas das empresas de grande porte, por exemplo. Tais diferenças, em geral, propiciam que esse tipo de empresa consiga desenvolver suas atividades com mais dinamismo e, teoricamente, com menor burocratização (OLIVEIRA; OLIVEIRA, 2016). 
Os critérios de definição do tamanho de uma empresa são definidos pelo seu faturamento ou receita anual bruta. O SEBRAE (2006) analisa que existem duas esferas que definem o porte de uma empresa: a federal e a estadual. No âmbito federal, é considerada uma microempresa aquela que possui uma receita federal igual ou superior a $\mathrm{R} \$ 240$ mil. Para as empresas de pequeno porte, são consideradas as que possuem uma arrecadação acima do valor de $R \$ 240$ mil e igual ou inferir a $R \$ 2$ milhões.

Maximiano (2010) afirma que as MPEs no Brasil possuem uma importância bastante relevante no cenário econômico do país, tendo em vista a sua posição estratégica na grande fatia de mercado referente ao setor de comércio, prestação de serviços e produção. Segundo o IBGE (2014) essas empresas foram responsáveis por cerca de $60 \%$ do Produto Interno Bruto (PIB) do Brasil nos últimos 10 anos, com um crescimento de $55 \%$ de volumização de mercado.

O infográfico abaixo (Figura 1) apresenta uma análise das MPE's segundo os dados do IBGE, tendo em vista o seu crescimento e impacto no Brasil:

Figura - O papel e o impacto das MPE's no Brasil (2016-2018)

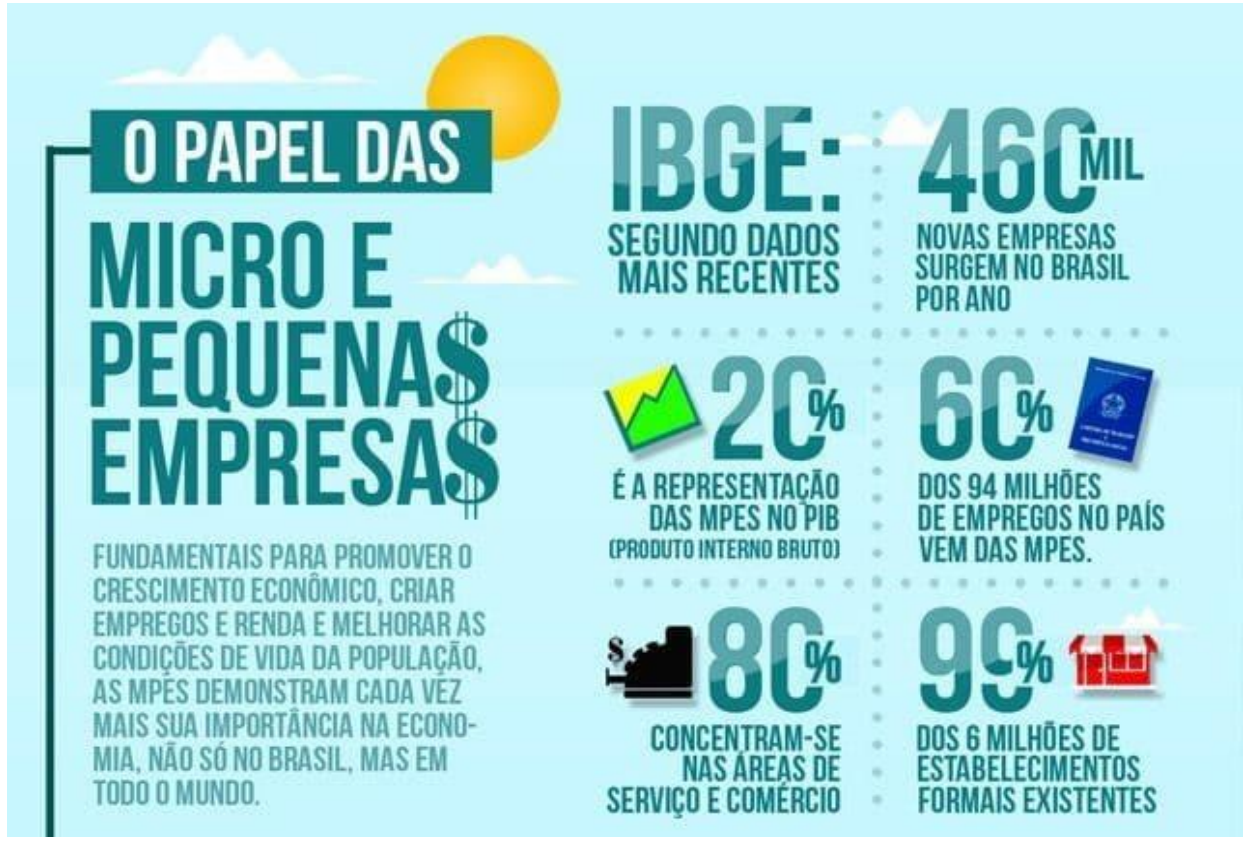

Fonte: Novo Negócio (2018) 
A Lei Geral da Micro e Pequena Empresa - Lei Complementar 123/2006 - determina o recolhimento mensal de impostos e a aplicação de percentuais favorecidos e progressivos, incidente em uma base de cálculo única de arrecadação de impostos e tributos, geridos pela União, Estados, Distrito Federal e Municípios (BRASIL, 2006).

Pode-se afirma que a Lei Geral (Lei Complementar 123/2006) foi uma das maiores conquistas das MPEs, pois estabeleceu e regulamentou os estímulos e incentivos para o desenvolvimento das empresas nos setores produtivos e comerciais. A aprovação dessa lei, em 2006, abriu também as portas para o Micro Empreendedor Individual (MEI) e para a Empresa de Pequeno Porte (EPP) com o estabelecimento do Estatuto Nacional da Microempresa (SILVA, 2004).

Segundo os dados do IPEA (2014) cerca de 37\% das empresas, principalmente as microempresas e empresas de pequeno porte, fecham as portas devido a insustentabilidade econômica e tributária, pois contribuem mais do que arrecadam. Maximiano (2010) aponta que a carga tributária brasileira é uma das mais altas do mundo, o que gera nas microempresas e empresas de pequeno porte um grande impacto econômico.

Marolli (2011) aborda que as micros e pequenas empresas sempre sofreram com a alta carga tributária do Brasil, além da burocratização na abertura do negócio e encargos trabalhistas. Entretanto, sempre manteve uma forte influência no aquecimento da economia no terceiro setor, principalmente no setor comercial, prestação de serviços e produção. Essas observações justificam a importância das MPEs para o mercado, sobretudo, para o desenvolvimento econômico local e regional.

Os resultados da pesquisa demonstraram que as micro e pequenas empresas no Brasil utilizam a contabilidade gerencial como uma das principais ferramentas de tomadas de decisão, principalmente com base no suporte das informações estratégicas de gestão de mercado.

O crescimento das MPE's provem de uma economia flutuante, principalmente pelo crescimento dos mercados emergentes e do boom das startups - nichos de inovação 
tecnológica. Observa-se que, segundo dados do IBGE, o crescimento das MPE's aumentou em 21\% nos últimos 10 anos, apesar da recessão econômica. Ainda de acordo com o IBGE, a prática da gestão contábil tem sido uma das grandes estratégias das empresas ao que se refere a gestão do seu investimento, ou seja, há uma preocupação de investir com mais cautela e com maior índice de certeza no negócio.

O gráfico 1 apresenta um aspecto de aumento no dimensionamento de MPE's de acordo com o período de 2001 a 2011, segundo o IBGE (2014). Esse crescimento também incide na contratação de pessoal e a taxa de crescimento (\%) só não superou as das grandes empresas, que durante o mesmo período aumento mais de $9,0 \%$ ao ano - cerca de $42 \%$ durante o período de 10 anos.

Gráfico 1 - Taxa de crescimento das MPE's no Brasil (2001 - 2011)

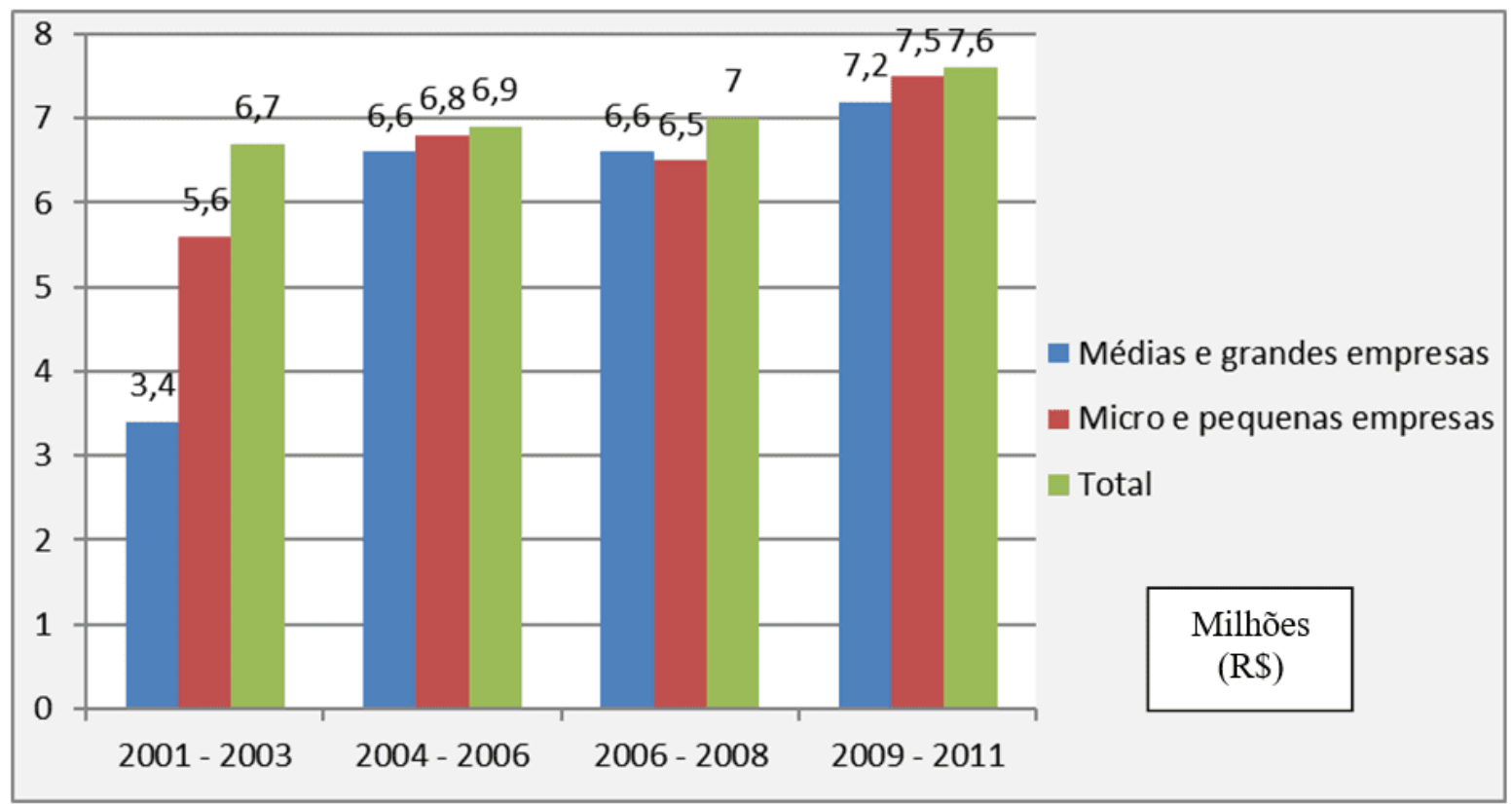

Fonte: Adaptado de IBGE (2014)

Oliveira e Oliveira (2006) analisam que o crescimento das MPE's pode ser apontado por alguns fatores pontuais, tais como a necessidade de empreender em um mercado emergente e o surgimento das oportunidades com a expansão das tecnologias. Nesse aspecto de cenário, os autores observam que o foco no planejamento estratégico 
passou a ser o principio norteador das empresas de menor porte, visto que a amplitude de mercado para setores de serviço e espaços emergentes de crescimento local.

A contabilidade gerencial possui uma atuação bastante vasta nas MPE's com enfoque em seus instrumentos, tendo em vista a sua capacidade de gerir a saúde contábil da empresa por meio da gestão organizacional e do planejamento estratégico. Moreira et al (2013) realizaram um estudo acerca da utilização dos instrumentos de contabilidade gerencial nas MPE's no Brasil de 2008 a 2012 (Gráfico 2):

Gráfico 2 - Instrumentos de contabilidade gerencial em MPE's no Brasil

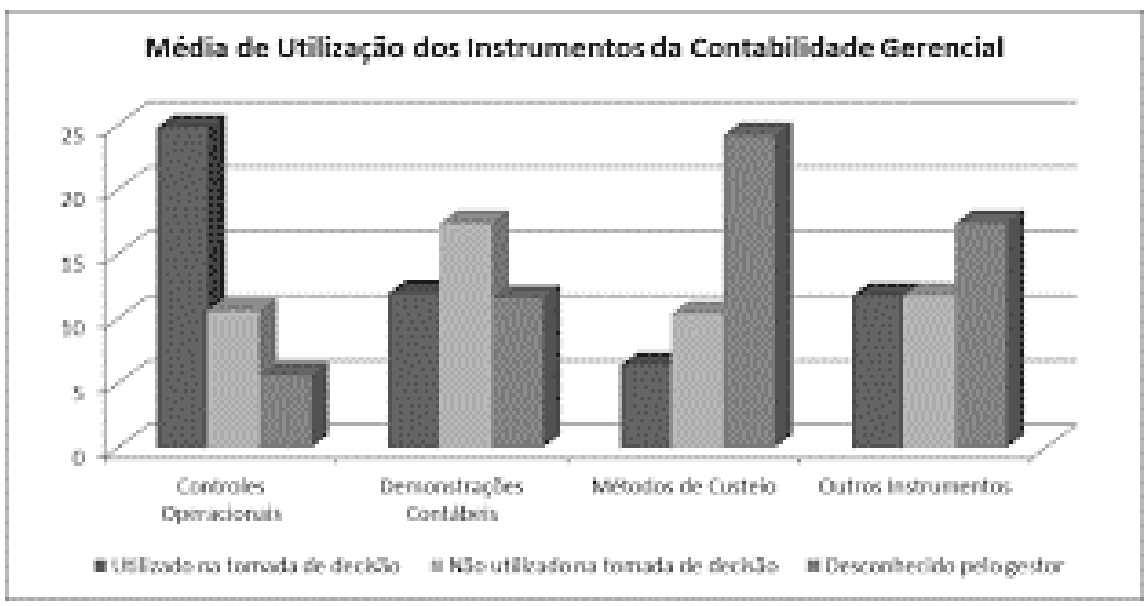

Fonte: Moreira et al (2013)

Observa-se que os métodos de custeio e os controles operacionais foram bem mais utilizados pelas MPE's durante o período de análise do estudo. Tendo em vista que o conhecimento do gestor e a sua aptidão com ferramentas de apoio gerencial, Moreira et al (2013) observaram que a contabilidade gerencial está bem mais próxima da gestão pela sua capacidade de realizar um acompanhamento mais gradual no aspecto da gestão contábil da organização, além da sua facilidade em ser absorvida pela equipe gestora.

Atkinson (2008) e Crepaldi (2011) observam a contabilidade gerencial como uma estratégia fundamental para negócios que objetivam uma gestão contábil mais sustentável e focada em uma metodologia de mercado mais dinâmica e emergente, 
ambos citando as MPE's. De tal modo, nota-se que a contabilidade gerencial se enraizou na filosofia do planejamento estratégico das empresas de pequeno e médio porte, a fim de objetivar eficiência e eficácia na gestão como um todo.

\section{CONSIDERAÇÕES FINAIS}

A tomada de decisão é uma etapa norteadora no processo administrativo, tendo em vista que é um fator decisivo para qualquer empresa o seu pleno e efetivo cumprimento de optar por melhores estratégias de mercado. Nesse aspecto, a contabilidade gerencial vem se tornando uma das áreas mais importantes para apoiar o planejamento estratégico das empresas, principalmente as MPE's.

O controle contábil propicia, além de um acompanhamento mais efetivo dos gastos, a possibilidade de observar o mercado a partir de uma visão mais holística, tendo por base o investimento de modo eficaz e sustentável. Observa-se que as empresas estão passando por uma transformação em seu modo de gerir o capital, bem mais antenados ao mercado financeiro. As MPE's estão alinhadas a esse novo padrão de mercado, na qual se utilizam dos mecanismos contábeis além do tradicional método operacional e de controle, mas com um uso mais estratégico e de apoio a tomada de decisão.

Assim sendo, observa-se que a contabilidade gerencial MPE's no Brasil possui uma tendência de amplificação no mercado, tendo em vista o seu suporte estratégico para suprir a organização com informações contábeis que otimizem a tomada de decisão. Esse novo panorama permite uma avaliação mais detalhada e sustentável do capital financeiro da empresa, de modo que o planejamento contábil seja apoiado em uma gestão mais tangível, qualitativa e com enfoque no empreendedorismo.

\section{REFERÊNCIAS}

ALMEIDA, Martinho Ismard Ribeiro de. Manual de planejamento estratégico. São Paulo: Atlas, 2001.

ATKINSON, Anthony A., Contabilidade gerencial. 2.ed. São Paulo: Atlas, 2008. 
BATISTA, Fabiano Ferreira et al. Uma investigação acerca da mortalidade das microempresas e empresas de pequeno porte da cidade de Sousa, PB. Revista de Administração, Contabilidade e Sustentabilidade - REUNIR, v. 2, n. 1, p. 56-71, jan./abr. 2012.

BRASIL. Lei Complementar 123/2006. 2006. Disponível em: http://www.planalto.gov.br/ccivil_03/leis/LCP/Lcp123.htm. Acesso em: 25 jun. 2018.

CANECA, Roberta Lira et al. A influência da oferta de contabilidade gerencial na percepção da qualidade dos serviços contábeis prestados aos gestores de micro, pequenas e médias empresas. Revista Pensar Contábil, v. 11, n. 43, p. 35-44, jan./mar. 2009.

CAMPOS, Luís; CANAVEZES, Sara. Introdução a globalização. 2007. Disponível em: https://dspace.uevora.pt/rdpc/bitstream/10174/2468/1/Introdu\%C3\%A7\%C3\%A30\%2 0\%C3\%A0\%20Globaliza\%C3\%A7\%C3\%A3o.pdf. Acesso em: 20 jun. 2020.

CHESNAIS, François. A mundialização do capital. São Paulo: Xamã, 1996.

CHIAVENATO, Idalberto. Administração: teoria, processo e prática. 3. ed. São Paulo: Pearson, 2000.

CORDEIRO, José Vicente B. de Mello; RIBEIRO, Renato Vieira. Gestão da empresa. In: FAE BUSINESS SCHOOL (Org.). Coleção Gestão Empresarial. São Paulo: FAE, 2002.

COSTA, D.F., YOSHITAKE, M. O controle e a informação contábil no planejamento tributário de uma pequena empresa para redução dos tributos e otimização dos lucros. In: CONGRESSO BRASILEIRO DE CONTABILIDADE, 17., 2004, Santos. Anais... Santos: CBC, 2004.

CREPALDI, Silvio Aparecido. Contabilidade Gerencial: Teoria e Prática. 3. ed. São Paulo: Atlas, 2006.

. Contabilidade Gerencial: teoria e prática. 5. ed. São Paulo: Atlas, 2011. 
DIARIO DE LIBERDADE. Trabalhadores na fábrica: século XIX. 2011. Disponível em: https://www.diarioliberdade.org/mundo/batalha-de-ideias/47889-ainterdepend\%C3\%AAncia-economia-pol\%C3\%ADtica-na-sociedade-atual.html. Acesso em: 21 jun. 2020.

FLICK, U. Introdução à Metodologia de Pesquisa: Um Guia Para Iniciantes. São Paulo: Penso, 2013.

GAMBARO, Carlos Maria. Globalização das economias: análise do pensamento de Guy Sormon. Revista de Direito Constitucional e Internacional, n. 34, jan./mar. 2001.

HOBSBAWN, Eric. A era dos extremos: o breve século XX. 2. ed. 29. reimpressão Traduzido

HORNGREN, Charles T., SUNDEM, Gary L.,STRATTON, Willian O. Contabilidade Gerencial. 12. ed. São Paulo: Pretice Hall, 2004. Versão traduzida para o português.

INSTITUTO BRASILEIRO DE GEOGRAFIA E ESTATístiCA. Micro e Pequenas Empresas: estudos e estatísticas. 2014. Disponível em: https://ww2.ibge.gov.br/home/estatistica/economia/microempresa/default.shtm. Acesso em: 10 jul. 2019.

INSTITUTO DE PESQUISAS ECONÔMICAS E APLICADAS. Micro e Pequenas Empresas no Brasil: mercado de trabalho e amplicação para o desenvolvimento. Brasília DF: IPEA, 2014. Disponível em: http://www.ipea.gov.br/agencia/images/stories/PDFs/livros/livros/livro_micro_pequen asempresas.pdf. Acesso em: 20 jun. 2018.

IUDÍCIBUS, Sérgio de. Contabilidade Gerencial. 6. ed. reimpr. São Paulo: Atlas, 2009.

MARTINELLO, Daniela. Gestão Empresarial: a importância da controladoria no processo decisório em uma empresa do ramo de confecções. 2011. 140 p. 
Trabalho de Conclusão do Curso de Ciências Contábeis. Universidade do Extremo Sul Catarinense - UNESC. Criciúma - SC.

MARQUES, Wagner Luiz. Contabilidade Gerencial à necessidade das Empresas. 2.ed. Paraná: Cidade, 2004.

MAROLLI, Gisele. Desenvolvimento Local: Um Estudo Baseado na Importância das Micro e Pequenas Empresas no município de Pitanga/PR. Dissertação de Mestrado. Canoinhas, 2011.

MURTEIRA, M. Economia do Mercado Global: Ensaio sobre Condicionantes Mega e Macro das Estratégias Empresariais, Lisboa, Presença, 1997.

MAXIMIANO, Antônio César Amaru. Introdução a administração. 7. ed. São Paulo: Atlas, 2010.

MOREIRA, R.L et al. A importância da informação contábil no processo de tomada de decisão nas micro e pequenas empresas. Revista Contemporânea de Contabilidade, v. 10, n.19, p. 119-140, 2013.

MOTA, Irenilce Farias; CIRINO, Elizângela da Silva. A era do conhecimento e a adoção do SPED - Sistema Súblico de Escrituração Digital - como impacto na contabilidade. Revista Razão Contábil \& Finanças, v. 1, n. 1, p. 1-7, jul./dez. 2010.

NETO, José Paulo; BRAZ, Marcelo. Economia política: uma introdução crítica.São Paulo: Editora Cortez, 2006.

NUNES JÚNIOR, Venilto Paulo. O conceito de soberania no século XXI. Revista de Direito Constitucional e Internacional, n. 42. jan./mar. 2003.

OLIVEIRA, Antonio Gonçalves de; OLIVEIRA, Gilson Batista de. Um estudo sobre a contribuição das micro e pequenas empresas na geração de emprego e renda brasileira. Revista da FAE, Curitiba, v. 9, n. 1, p. 95-105, 2006.

PADOVEZE, Clovis Luis. Contabilidade Gerencial. Curitiba: IESDE, 2012 
PÁDUA, E. M. M. D. Metodologia da pesquisa: abordagem teórico prática. 10. ed. Campinas: Papirus, 2004.

PAULA, Luiz Fernando; PIRES, Manoel. Crise e perspectivas para a economia brasileira, Estudos Avançados, v. 31, n.89, 2017.

PIZZOLATO, Nélio Domingues. Introdução à Contabilidade Gerencial. 2. ed. rev. e ampl. São Paulo: Makron Books, 2000. P. 193 - 209.

POSSAS, M. Elementos para uma integração micro-macrodinâmica na teoria do desenvolvimento econômico. Revista Brasileira de Inovação, v. 1, Ano 1, p. 123149, jan./ jun. 2002.

SANT'ANNA, Roberto de O. Contabilidade Gerencial. [Apostila digital]. 2011. Disponível em: <http://www.unisa.br/conteudos/6402/f1603556549/apostila/apostila.pdf>. Acesso em: 20 set. 2018.

SANTOS, Milton. Por uma outra globalização: do pensamento único à consciência universal. Rio de Janeiro: Record, 2000.

SANTOS, Boaventura de Sousa (Org.). A globalização e as ciências sociais. São Paulo: Cortez, 2005.

SARAMAGO, J. Ensaio sobre a cegueira. São Paulo, Brasil: Companhia das Letras, 1995.

SEBRAE. Lei Geral das Micro e Pequenas Empresas. Disponível em: http://www.leigeral.com.br/. Acesso em: 20 jun. 2018.

SILVA, João Braz. O Uso de Ferramentas de Gestão Empresarial como Fator de Sucesso dentro das Empresas: um Estudo de Caso. Dissertação - Mestrado em Engenharia de Produção, UFSC, Florianópolis, 2004. 
THERBORN, Goran. Globalização e desigualdade: questões de conceituação e esclarecimento, Sociologias, Porto Alegre, ano 3, n. 6, jul/dez 2001, p. 122-169

VICO MANAS, Antonio. Administração de sistemas de informação. 8. ed. São Paulo: Erica, 2012.

Enviado: Junho, 2020.

Aprovado: Julho, 2020. 